\title{
Prostatektomia radykalna leczeniem pierwszego wyboru u chorych na raka stercza wysokiego ryzyka i miejscowo zaawansowanego
}

\author{
Andrzej Borkowski
}

\section{Radical prostatectomy is a first choice treatment in high risk and locally advanced prostatic cancer}

Publikacja na podstawie wystąpienia podczas I Konferencji Naukowej czasopisma Nowotwory „Debaty Onkologiczne” 5 i 6 kwietnia 2013 roku.

W ostatnich latach obserwujemy ewolucję poglądów na temat leczenia chorych na raka stercza wysokiego ryzyka i na raka stercza miejscowo zaawansowanego. Omawiamy te grupy wspólnie, gdyż ich precyzyjne rozgraniczenie jest zazwyczaj niemożliwe. Z danych SEER w USA wiemy, że pomiędzy rokiem 1995 a 2001 agresywna terapia chorych na raka cT3 wzrosła o 11\% i w 2001 roku poddawano jej już $70 \%$ chorych. Radioterapia, z 20\% wzrostem, stosowana była 6,5 razy częściej niż chirurgia, prostatektomię radykalną u chorych w tym stadium zaawansowania stosowano jedynie u $12 \%$ chorych, co oznaczało spadek prawie o połowę. Nieco częściej, bo u prawie 30\% była wykonywana u chorych poniżej 55 roku życia [1]. Jeszcze w 2008 roku w Guidelines of European Association of Urology napisano, że prostatektomia radykalna może być leczeniem opcjonalnym u chorych z guzem T3a, Gleason > 8 tylko wówczas, jeżeli PSA jest niższe od 20ng/ml. Radioterapiauznana była powszechniezametodę pierwszego wyboru leczenia chorych na raka stercza miejscowo zaawansowanego i raka stercza wysokiego ryzyka. Pogląd ten ugruntowało ogłoszenie wyników badań EORTC 22683 [2], RTOG 8610 [3] i RTOG [4], które pokazały dalszą poprawę wyników przeżycia całkowitego (OS — Overall Survival) i przeżycia specyficznego dla raka (CSS - Cancer Specific Survival) u tych chorych, u których radioterapię połączy się z długotrwałą hormonoterapią. Warto zauważyć, iż Bolla już wtedy wyraźnie podkreślał, że badania te wykazały wyższość radioterapii z hormonoterapią nad samą radioterapią, ale nie nad prostatektomią radykalną [2].
Jeszcze nie tak dawno stawiano pytanie, czy chorych na raka stercza o wysokim ryzyku progresji i/lub miejscowo zaawansowanego należy leczyć radykalnie, czy ze względu na duże prawdopodobieństwo przerzutów logiczniejsze jest leczenie hormonalne (ADT - Androgen Deprivation Therapy). Nie podlega obecnie wątpliwości, że leczenie radykalne przynosi znacznie większą korzyść zarówno w zakresie OS, jak i CSS. Udowodniono to zarówno dla radioterapii $[5,6]$, jak i dla prostatektomii radykalnej.W przypadku tej ostatniej korzyść ta dotyczy również chorych z przerzutami do węzłów chłonnych bez przerzutów odległych [7, 8]. Nawet w przypadku guzów cT4 przeżycia po prostatektomii radykalnej czy radioterapii są znacznie lepsze od przeżyć chorych nieleczonych czy poddanych ADT [9]. Od dawna już nie obowiązuje górna granica PSA - $20 \mathrm{ng} / \mathrm{ml}$, powyżej której nie zalecano leczenia chirurgicznego [10], a CSS dla chorych z PSA 20-50 ng/ml, 50-100 ng/ml i powyżej $100 \mathrm{ng} / \mathrm{ml}$, jeżeli nie łączy się z niekorzystną patologią, może osiągnąć odpowiednio 91\%,85\%, 80\% [11].

Między rokiem 1991 a 2005 śmiertelność na raka stercza obniżyła się w Stanach Zjednoczonych o 40\% [12]. Od nie tak dawna wiemy, że aktywne leczenie chorych na nowotwory o niskim ryzyku progresji (Gleason 6 i najprawdopodobniej w większości Gleason 7) nie wpływa, albo wpływa w minimalnym stopniu na OS i CSS $[13,14]$. Postęp ten dokonał się głównie dzięki wcześniejszemu wykrywaniu oraz coraz częstszemu i coraz bardziej skutecznemu leczeniu chorych na nowotwory wysokiego ryzyka i miejscowo zaawansowane [12].

Klinika Chirurgii Ogólnej i Kolorektalnej

I Katedra Chirurgii

Uniwersytet Medyczny w Łodzi 
Tak więc wiemy już dzisiaj na pewno, że nowotwory stercza wysokiego ryzyka progresji i miejscowo zaawansowane należy leczyć agresywnie. Pozostaje pytanie, czy zaczynać od radioterapii czy od prostatektomii radykalnej.

Ryzyko progresji w tej grupie nowotworów zależne jest w dużej mierze od definicji opartej na różnym doborze czynników ryzyka; PSA, stadium zaawansowania, stopień złośliwości histologicznej [15]. Inaczej dobrane rzutują na wyniki odlegle, o czym należy pamiętać, porównując rezultaty radioterapii i chirurgii. Ponieważ są to nowotwory o dużym ryzyku wystąpienia przerzutów odległych i śmierci z powodu nowotworu, guz pierwotny musi być leczony jak najbardziej skutecznie, bowiem najprawdopodobniej czynniki wzrostu wytwarzane przez guz pierwotny przygotowują miejsce przyszłych przerzutów i następowej progresji [16]. Dodatnie marginesy po prostatektomii radykalnej guzów T3 stwierdza się od 27-56\%, przetrwałe komórki w biopsji po radioterapii do 81 Gy, z użyciem technik 3D-CRT i IMRT aż u 38\% chorych poddanych biopsji [17]. Nie potrafimy precyzyjnie ustalić, jak bardzo wyniki te przekładają się na rokowanie. Dlatego ani ten fakt, ani twierdzenie, że są to guzy o najgorszym rokowaniu, czy też to, że radioterapeuci dysponują coraz lepszymi technikami napromieniania, obniżającymi odsetek wznów biochemicznych, nie może być argumentem za żadnym ze sposobów leczenia. Wiemy bowiem z dotychczasowego doświadczenia, że wyniki dotyczące przeżycia bez wznowy biochemicznej czy klinicznej nie przekładają się na wyniki OS i CSS.

Jedynym rozsądnym sposobem porównania obu technik są prospektywne randomizowane badania kliniczne. Ponieważ takie nie istnieją i nieprędko powstaną, musimy opierać się na wynikach odległych dotyczących OS i CSS, najlepiej z renomowanych ośrodków onkologicznych, które stosują oba te sposoby leczenia, a jeszcze lepiej — na metaanalizach wieloośrodkowych bądź opartych na bazach danych z dużych rejestrów krajowych i międzynarodowych.

Pierwsze sygnały, że chirurgia może powodować korzystniejsze, a na pewno nie gorsze efekty niż radioterapia, odległe OS i CSS, pochodziły z porównania opublikowanych po 2004 roku informacji na temat prostatektomii radykalnych z pojedynczych ośrodków urologicznych [18-20] z wynikami po radioterapii z badań klinicznych RTOG-8610 i EORTC 22863 [21, 22]. 5-letnie DSS po prostatektomii radykalnej chorych z guzem T3a wynosiło w tych trzech ośrodkach 95\%, 98,7 i 100\% [20], a po radioterapii — 94\% [2]. 10-letnie DSS wynosiło odpowiednio 90-91,6\% po prostatektomii radykalnej i 77\% po radioterapii [22]. Często wysuwa się zarzut, iż chorzy kierowani do radioterapii mają nowotwór w gorszym stadium zaawansowania. W badaniu RTOG 8610 chorych podzielono na 3 podgrupy pod względem ryzyka progresji. OSS chorych z podgrupy o najniższych czynnikach ryzyka po 5 i 8 latach wyniosło odpowiednio $93 \%$ i $88 \%$, co nadal jest wynikiem gorszym niż OSS po 5 i 10 latach dla wszystkich chorych leczonych chirurgicznie (bez wykluczenia tych z najgorszymi czynnikami ryzyka), odpowiednio 95-90\% i 98,7-91,6\% [20, 21].

Można oczywiście przedstawić zarzuty, iż w tym czasie operowano głównie chorych z guzem T3a, a techniki napromieniania były niedoskonałe. Jednak to te wyniki pozwoliły po raz pierwszy na postawienie tezy, iż u tych chorych leczenie chirurgiczne może być równie skuteczne jak radioterapia, a być może lepsze.

Jak wygląda to porównanie obecnie, gdy dzięki poprawie techniki operacyjnej obserwujemy znaczne obniżenie dodatnich marginesów po prostatektomii radykalnej, gdy wprowadzono rozszerzoną limfadenektomię, radioterapię zaś łączy się obowiązkowo z hormonoterapią, a nowe techniki pozwalają na precyzyjniejsze namiary i zwiększenie dawki? Przypatrzmy się metaanalizom, jak i retrospektywnym badaniom z przodujących ośrodków urologicznych i onkologicznych dotyczącym chorych z wysokim ryzykiem progresji, opublikowanym w ostatnich latach.

Cooperberg z Universytetu w Kalifornii wrazze badaczami z Memorial Sloan-Catering Cancer Center w Nowym Jorku analizowali 7538 chorych na raka ograniczonego do narządu, z rejestru CAPSURE. Ryzyko CSS oceniane było według nomogramów Kattana i sytemu oceny ryzyka CAPRA. Poddanie chorych prostatektomii radykalnej obniżało znacząco śmiertelność z powodu raka (Cancer specific mortality - CSM) w stosunku do chorych napromienianych czy leczonych pierwotnie hormonalnie, a co bardzo ważne — największe różnice obserwowane były wśród chorych na raka o wysokim ryzyku progresji. Zrównanie ryzyka CSM w grupie chorych napromienianych i operowanych następowało dopiero wówczas, kiedy chorym z grupy prostatektomii radykalnej zwiększano sztucznie o 35 punktów wynik wskazujący na stopień ryzyka wg nomogramu Kattana [23].

W dużej pracy zbiorczej firmowanej przez kilka ośrodków z Kanady, Francji, Włoch i USA, opartej na 416567 chorych na raka stercza ograniczonego do narządu z rejestru SEER stwierdzono, że 10-letnia CSM w grupie wysokiego ryzyka była mniejsza po prostatektomii radykalnej niż po radioterapii u chorych < 69 roku życia, równa radioterapii u chorych między 69 a 70 rokiem życia, a gorsza jedynie u chorych $>80$ roku życia [24].

W retrospektywnej pracy A. Tewariego z dwóch uniwersyteckich ośrodków w Nowym Jorku, przeprowadzonej na 3159 chorych, poddano analizie 453 z nich z Gleason $\geq 8$. Stwierdzono w 15-letnich obserwacjach, że mediana OS wynosiła 6,7 lat dla chorych po radioterapii i 9,7 lat po prostatektomii radykalnej, ryzyko CSM było o 49\% niższe po prostatektomii radykalnej niż po napromienianiu [25].

W metaanalizie PC Albertsena opartej na 1618 chorych z Connecticut Tumor Registry autorzy stwierdzili, iż spodzie- 
wane 10-letnie CSS dla chorych operowanych, napromienianych i obserwowanych wynosi odpowiednio 97\%, 88\% i $81 \%$, ale już w grupie chorych wysokiego ryzyka różnice między chirurgią i radioterapią są znacznie większe: 90\% dla chirurgii i $80 \%$ dla radioterapii. Co również niezwykle istotne, 10 letnie OS są zdecydowanie lepsze po prostatektomii radykalnej, nie różnią się natomiast znacząco miedzy radioterapią a obserwacją [26].

Bardzo ważna także praca pochodzi z Memorial Sloan-Kattering Cancer Center i sygnowana jest na pierwszym miejscu przez radioterapeutę MJ Zelefsky'ego [27]. Tezą tej pracy jest przekonanie, iż skuteczne zniszczenie guza pierwotnego (local control) jest najważniejsze dla ograniczenia przerzutów odległych i CSM. Porównywano wyniki odlegle 1318 chorych operowanych i 1062 napromienianych z powodu raka stercza w stadium T1c-T3b i w każdym stopniu zróżnicowania. 8-letnie prawdopodobieństwo CSS dla całej grupy wyniosło 98,6\% dla chorych operowanych i 95,3\% dla chorych napromienianych, ale w grupie chorych wysokiego ryzyka różnice te były zdecydowanie wyższe. Wniosek autorów jest jasny: U chorych z grupy wysokiego ryzyka prostatektomia radykalna łączy się z mniejszym ryzykiem powstania przerzutów odległych i CSM niż u chorych napromienianych. Pracy tej stawia się zarzut, iż chorzy napromieniani byli starsi i w wyższym stadium zaawansowania. Jednak autorzy, uprzedzając ten zarzut, dla porównania, grupowali chorych ściśle wg nomogramów Kattana i NCCN klasyfikacji grup ryzyka, a ponadto dla wyrównania różnic wiekowych wg modelu regresji ryzyka (risk-regression model).

Na marginesie trzeba dodać, iż jest to często podnoszony problem. O ile można się zgodzić, że jest on częściowo słuszny dla chorych w stadium T3b, to trzeba podkreślić, iż - o czym niechętnie wspominają radioterapeuci — zarzut ten działa i w drugą stronę. Chorzy z guzem w stadium cT3a w 40\% okazują się mieć stadium pT2 [28]. Po prostatektomii radykalnej są oni wykluczani z analizy obejmującej chorych na raka miejscowo zaawansowanego, i zaliczani do grupy chorych na raka ograniczonego do narządu (organ confined), a po napromienianiu są nadal traktowani jako chorzy na raka miejscowo zaawansowanego.

Wszystkie te argumenty wpłynęły na to, że w Guidelines of European Association of Urology już od 2010 roku prostatektomia radykalna jest leczeniem opcjonalnym do radioterapii dla chorych na raka stercza cT3a, Gleason 8-10 i PSA > 20 ng/ml, a w ramach leczenia multidyscyplinarnego - nawet dla wybranych chorych z T3b-T4, N0 lub N1.

Co zyskujemy, jeżeli zaczynamy leczenie tych chorych od prostatektomii radykalnej:

1. Korzyść w zakresie OS i CSS. Wszystkie metaanalizy oparte na bazach danych z dużych rejestrów krajowych i międzynarodowych, jak i o dane retrospektywne z przodujących ośrodków w USA, gdzie dotychczas faworyzowano radioterapię, pokazują lepsze wyniki po leczeniu chirurgicznym niż po radioterapii (po dokładnym uwzględnieniu podgrup ryzyka wg D’Amico i (APRA). Największe różnice na korzyść prostatektomii radykalnej odnotowano u chorych z grupy wysokiego ryzyka.

2. Prostatektomia radykalna pozwala na dokładne określenie patologicznego stadium zaawansowania i stopnia zróżnicowania.

3. Rozszerzona limfadenektomia poprawia wyniki w zakresie CSS, zwłaszcza, jeżeli stwierdza się przerzuty do mniej niż 3 węzłów.

4. Wczesne wykrycie wznowy miejscowej, o czym świadczy minimalny nawet wzrost stężenia PSA po prostatektomii radykalnej, pozwala to na precyzyjne ustalenie wskazań do adiuwantowej (adjuvant) lub ratującej (salvage) radioterapii. Brak precyzji w interpretacji stężenia PSA po radioterapii, utrudniony dodatkowo przez hormonoterapię, powoduje, że leczenie ratujące jest najczęściej spóźnione, gdyż przekroczony został moment, do którego mogłoby ono być skuteczne.

5. $20-40 \%$ chorych z cT2 (downstaging) i znaczny odsetek chorych z PT3 unika jakiegokolwiek dalszego leczenia.

6. Prostatektomia radykalna po radioterapii jest trudniejsza i obciążona większym odsetkiem powikłań niż radioterapia po prostatektomii radykalnej.

7. $50-75 \%$ chorych unika ADT, u pozostałych można ją opóźnić. Może być dość precyzyjnie sterowana wyjściowym PSA i PSA DT.

8. U chorych z obciążeniami sercowo-naczyniowymi korzyść z połączenia RT i ADT jest niwelowana przez śmiertelność naczyniowo-sercową.

Na zakończenie ostatnie przesłanie. Podczas Kongresu ASCO w 2012 roku przedstawiono metaanalizę z medianą obserwacji 71 miesięcy, opracowaną głównie przez radioterapeutów i urologów z Cleveland (USA), opartą na wynikach leczenia 137427 chorych na raka stercza z rejestrów SEER i Medicare. U 43,9\% chorych wykonano prostatektomię radykalną, u 44,2\% napromienianie ze źródeł zewnętrznych, u 12,4\% - brachyterapię. Najwięcej powikłań urogenitalnych i żołądkowo-jelitowych występowało po napromienianiu. Średni koszt leczenia podstawowego, jak i następowych powikłań wynosił 6412 dolarów USA na jednego chorego leczonego napromienianiem i 3205 dolarów - po prostatektomii radykalnej. Dlaczego nie leczyć taniej i lepiej!

\section{Prof. dr hab. med. Andrzej Borkowski}

Klinika Urologii Ogólnej, Onkologicznej i Czynnościowej Warszawski Uniwersytet Medyczny

Szpital Kliniczny Dzieciątka Jezus — Centrum Leczenia Obrażeń

ul. Lindleya 4, 02-013 Warszawa

e-mail: andrzej.borkowski@wum.edu.pl 


\section{Piśmiennictwo}

1. Denberg TD, Glode LM, Steiner JF i wsp. Trends and predictors of aggressive therapy for clinical locally advanced prostate carcinoma. $B J U$ International 2006; 98: 335-340.

2. Bolla $M$, Collette $L$, Blank $L$ i wsp. Long term results with immediate androgen suppression and external irradiation with locally advanced prostate cancer (an EORTC study): a phase III randomized trial. Lancet 2002; 360: 103-206.

3. Pilepich MV, Winter K, John MJ i wsp. Phase III radiation therapy oncology group (RTOG) trial 86-10 of androgen deprivation adjuvant to definitive radiotherapy in locally advanced carcinoma of the prostate. Int J Radiat Oncol Biol Phys 2001; 50: 1243-1252.

4. Pilepich MV, Winter K, Lawton CA i wsp. Androgen suppression adjuvant to radiotherapy in prostate carcinoma: long terms results of phase III RTOG 85-31. J Radiat Oncol Biol Phys 2005; 61: 1285-1290.

5. Widmark A, Klepp O, Solberg A i wsp. Endocrine treatment, with or without radiotherapy, in locally advanced prostate cancer (SPCG-7/SFOU-3): an open randomized phase III trial. Lancet 2009; 373: 301-308.

6. Warde $\mathrm{P}$, Mason M, Ding K i wsp. Combined androgen deprivation therapy and radiation therapy for locally advanced prostate cancer: a randomized, phase 3 trial. Lancet 2011; 378: 2104-2111.

7. Ghavamian R., Bergstralh EJ, Blute ML i wsp. Radical retropubic prostatectomy plus orchiectomy versus orchiectomy alone for pTxN+ prostate cancer; a matched comparison. J Urol 1999; 161: 1223-1228.

8. Engel J, Bastian PJ, Baur H i wsp. Survival benefit of radical prostatectomy in lymph-positive patients with prostate cancer. Eur Urol 2010; 57: 754-7761.

9. Johnstone PAS, Ward KC, Goodman M i wsp. Radical prostatectomy for clinical T4 prostate cancer. Cancer 2006; 106: 2603-2609.

10. Spahn M, Joniau S, Gontero P i wsp. Outcome predictors of radical prostatectomy in patients with prostate-specific antigen greater than $20 \mathrm{ng} / \mathrm{ml}$ : a European multi-institutional study of 712 patients. Eur Urol 2010; 58: 1-7.

11. Brandli DW, Koch MO, Foster RS i wsp. Biochemical disease-free survival in patients with high prostate-specific antigen level $(20-100 \mathrm{ng} / \mathrm{ml})$ and clinically localized prostate cancer after radical prostatectomy. BJU International 2003; 92: 19-23.

12. Etzioni R, Gulati R, Tsodikov A i wsp. The prostate cancer conundrum revisited. Treatment changes and prostate cancer mortality declines. Cancer 2012; 118: 5955-5963.

13. Vickers a, Bennette C, Steineck G i wsp. Individual estimation of the benefit of radical prostatectomy from the Scandinavian prostate cancer group randomized trial. Eur Urol 2012; 62: 204-209.

14. Wilt TJ, Brawer MK, Jones KM i wsp. Radical prostatectomy versus observation for localized prostate cancer. N Engl J Med 2012; 367: 203-213.

15. Yossepowitch O, Eggener SE, Bianco FJ i wsp. Radical prostatectomy for clinically localized, high risk prostate cancer: critical analysis of risk assessment methods. J Urol 2007; 178: 493-499.
16. Kaplan RN, Rafii S., Lyden D. Preparing the "soil": the premetastatic niche. Cancer Res 2006; 66: 11089-11093.

17. Zelefsky MJ, Yamada Y, Kollmeier A i wsp. Long-term outcome follow ing three dimensional conformal/intensity-modulated external-beam radiotherapy for clinical stage T3 prostate cancer. Eur Urol 2008; 53: 1172-1179.

18. Ward JF, Slezak JM, Blute ML i wsp. Radical prostatectomy for clinically advanced (cT3) prostate cancer since the advent of prostate-specific antigen testing: 15-year outcome. BJU Int 2005; 95: 751-756.

19. Martinez de la Riva M, Lopez-Tomasety JB, Dominguez RM i wsp. Radical prostatectomy as monotherapy for locally advanced prostate cancer (T3a): 12 years follow-up. Arch Esp Urol 2004; 57: 679-92.

20. Hsu ChY, Joniau S, Oyen R i wsp. Outcome of surgery for clinical unilateral T3a prostate cancer: a single-institution experience. Eur Urol 2007; 51: 121-129.

21. Roach M, Lu J, Pilepich MV i wsp. Predicting long-term survival, and the need for hormonal therapy: a metaanalysis of RTOG prostate cancer trials. Int J Radiation Oncol Biol Phys 2000; 47: 617-627.

22. Roach III M, Bae K, Speight J i wsp. Short-term neoadjuvant androgen deprivation therapy and external-beam radiotherapy for locally advanced prostate cancer: long-term results of RTOG 8610. J Clin Oncol 2008; 26: 585-5591.

23. Cooperberg MR, Vickers AJ, Broering JM i wsp. Comparative risk-adjusted mortality outcomes after primary surgery, radiotherapy, or androgen-deprivation therapy for localized prostate cancer. Cancer 2010; 116: 5226-5234.

24. Abdollah F, Sun M, Thuret R i wsp.A competing-risks analysis of survival aftter alternative treatment modalities for prostate cancer patients. Eur Urol 2011; 59: 88-95

25. Tewari A, Divine G, Chang P i wsp. Long-term survival in men with high grade prostate cancer: a comparison between conservative treatment, radiation therapy and radical prostatectomy — a propensity scoring approach. J Urol 2007; 177: 911-915.

26. Albertsen PC, Hanley JA, Penson DF i wsp. 13-year outcomes following treatment for clinically localized prostate cancer in a population based cohort. J Urol 2007; 177: 932-936.

27. Zelefsky MJ, Eastham JA, Cronin AM i wsp. Metastasis after radical prostatectomy or external beam radiotherapy for patients with clinically localized prostate cancer: a comparison of clinical cohorts adjusted for case mix. J Clin Oncol 2010; 28: 1508-1513.

28. Briganti A, Joniau S., Gontero P i wsp. Identifying the best candidate for radical prostatectomy among patients with high-risk prostate cancer. Eur Urol 2012; 61: 584-592.

29. Ciezki JP, Reddy ChA, Angermeier K i wsp. Long-term toxicity and associated cost of initial and subsequent toxicity-related intervention for patients treated with prostatectomy, external beam radiotherapy or brachytherapy: SEER/Medicare database study. Genitourinary Symposium, Prostate Cancer, oral session A, ASCO Meeting 2012. 